\title{
How to Implement Supervision Programs at School
}

\author{
Raita Gina Aprilina*, Nugraha \\ Educational Administration Program, School of Postgraduate \\ Universitas Pendidikan Indonesia \\ Bandung, Indonesia \\ *raitaretta@gmail.com
}

\begin{abstract}
The qualitative research method that was used in this research aimed to reveal supervision programs that has been implemented in Special Needs Schools. The method used in this research is interviewing school principals in Cluster 38 Bandung that consist of five Special Needs School. To gain best supervision programs at school, this article therefore identifies effective supervision program starting from how to set performance standards, and ending with corrective actions taken in the implementation of supervisory management at school. The result shows that in setting performance standards, they use the standard that has been existed seen long ago. The supervision programs consist of classroom visit, weekly administration checking, and monthly evaluation. For the corrective action, it can be done by giving feedback, promoting teacher professional development, assisting the underperforming teachers, and linking reviews to reward and disciplinary procedures.
\end{abstract}

Keywords-corrective actions, performance standard, supervision program

\section{INTRODUCTION}

The success of education cannot be separated from the role of a supervisor in the field of education that seeks to find educational problems and always fix the weaknesses that occur [1]. The purpose of supervision closely relates with the purpose of education at schools that is to help teachers undertake their roles to get the set objectives met.

Teachers have potential to have creativity and improve their performance. However, many factors can block them from developing their potentials, whether in the form of their ability in conducting the teaching-learning process or the educational facilities and infrastructure provided. Therefore, continuous supervision is importantly needed with the structured supervision program which is an important framework in educational management.

The important key in the process of school management is the function of school supervision in the relationship between plan and delegated activities. The process of monitoring activities in supervision can be interpreted to ensure that all organizational activities are carried out as planned and at the same time it is an activity to evaluate and correct any deviations that will interfere with the achievement of goals [2]
Supervision is designed to support the process of teaching and learning in schools. Lack of supervision could result into inadequate preparation by teachers, negative attitude of students toward unconducive school climate [3].

Teachers have to update their abilities in the field of education provision in this digital age, there is individual responsibility to continuously upskill and renew one's knowledge, as well as a wider responsibility across government and businesses in terms of making learning and the education system accessible, efficient and relevant. It can be succeeding if supervisor takes the right role with the structured supervision program to support

\section{A. Related Work}

This paper focused on three categories. They are educational supervision, performance standard, and corrective actions

1) Educational supervision: In educational supervision, supervisor helps teacher to develop their potential for their work and for themselves based on its scientific principles, such as assessment of the improvement of teaching and learning process, empowering teachers and enhancing the quality of teaching. The motivation behind supervision is to work helpfully with teachers to improve guidance. The objective of the supervisor is not just to assist teachers with tackling quick issues yet additionally to draw in with teachers in the investigation of the cycles of educating and learning. Certainly, improvement of guidance is a long term, consistent cycle that requires collaboration [4].

Supervision can improve the quality of main activities at school as well, which is improvement of the teaching and learning process [5].

In spite of the fact that supervision can be comprehensively imagined as any arrangement of activities intended to improve the instructing learning measure, it includes a pattern of efficient planning, observation, diagnosis, change, and recharged planning.

2) Performance standard: Supervision of teaching performance in a professional development perspective, crucial to improve a meaningful and sustainable learning. 
Therefore, it is very important to set performance standards, within the scope in which is developed the action and the current program objectives [6].

There is an interest for responsibility and quality improvement in the teaching profession. Teachers are required to show the capabilities (knowledge, aptitudes and attitudes) needed to perform their assignments and to take part in nonstop professional development.

Performance is a work achievement that has been achieved by someone. Work performance is the final result of an activity that someone has done to achieve an aim. The achievement of this work is also a form of comparison the work of a person with a predetermined standard. If the work done by someone in accordance with work standards or even exceeding the standard it can be said that the performance achieves good achievements.

Teacher performance standards are related to teacher quality in carrying out duties such as working with students individually, lesson preparation and planning, utilization of instructional media, involving students in various learning experiences, and active leadership from the teacher

3) Corrective action: Corrective action is the activity of reacting to a process problem, getting it under control through containment actions, and then taking the action needed to stop it from happening again [7]. Corrective actions are about improving behaviour or performance of the process.

Regulation of the Minister of National Education number 412007 regulates the supervision of the process learning which includes monitoring and supervision. Based on these regulations, corrective actions of academic supervision can be done by the principal by giving examples, discussions, training, and consultation. The principal can choose alternative corrective actions above in accordance with the analysis of the results of academic supervision against the components mentioned above.

The principal determines the teacher group by what kind of problem, on which component, can be given a corrective action by giving examples, discussion, training, and consultation. In every corrective action activity chosen by the principal must formulate the background and the purpose of selecting activities, as well as targets that must be achieved. The matters mentioned above must be noted in the corrective action program.

\section{B. Our Contribution}

This paper presents the strategies and process on the implementation of supervision programs in the Special Needs School from Cluster 38 Bandung Regency. This study hopefully can give some illustration on how supervision programs implemented in Special Needs School. Therefore, in the future, it can be evaluated and future research can help those schools to review and upgrade the supervision programs to be better.

\section{MethodOLOGY}

The qualitative research method was used in this research. It is aimed to reveal supervision programs that has been implemented in Special Needs Schools. The method used in this research is interviewing school principals and two teachers from each school in Cluster 38 Bandung Regency that consist of five Special Needs School.

\section{DISCUSSION}

The result of interviewing school principals, in setting performance standard, they are using the standard that has been existed seen long ago. The school principals use the performance standard that has been formed by the Minister of National Education as well. They do not make their own performance standard or renew it. They always use the same things year by year.

In the observation process, they have classroom visit, weekly administration checking, and monthly evaluation. Weekly administration checking usually collect inspection of students' exercises or progress, lesson observation, and other records of work, management of homework for instance. Unfortunately, they often face significant practical, conceptual, and socio affective challenges. Regarding the practical challenges, they usually lack sufficient time to properly conduct the supervision of their teachers.

For the corrective action, the school principals give some feedback for the teacher. They also held some workshop and seminar to upgrade teacher's knowledge. Besides, the school principals give some rewards for the best performing teacher and punishment for those who miss some tasks or performance standards as well.

\section{CONCLUSION}

The result shows that in setting performance standards, they use the standard that has been existed seen long ago. However, the world is always changing. We have to adapt to the situation nowadays. Many ways can be done in setting performance standard. For example, doing appraisal with collection of data and appraisal interview can help [8]. From that way, we can know what kind of tasks that needed in today's situation. What standard can be change, remove or review.

After the observation, it will be better if there is some discussion between supervisor and teacher. They can discuss the results (obtain feedback, recognise well-performed areas and suggest areas for improvement). The supervisor and the teacher work out a plan for improvement and follow-up actions if necessary. The supervisor and the teacher sign on the evaluation report. They then follow up the recommendations (if necessary) and evaluate the progress continuously.

They also tend to focus more on administrative duties than on their teachers' professional development. Further research can find out how to solve the challenges of supervision that happened in Special Needs School. 


\section{REFERENCES}

[1] I. Haris, F.A. Naway, W.T. Pulukadang, H. Takeshita and I.V. Ancho, "School supervision practices in the indonesian education system; perspectives and challenges," J Soc Stud Educ Res., vol. 9, no. 2, pp. 366-387, 2018.

[2] A. Sudrajat, Pengertian pendekatan, strategi, metode, teknik dan model pembelajaran. Bandung: Sinar Baru Algensindo, 2008.

[3] E.P. Oghuvbu, "Determinants of Effective and Ineffective Supervision in Schools: Teachers Perspectives," Online Submission, 2007.
[4] W.K. Hoy and P.B. Forsyth, Effective supervision: Theory into practice. Random House, 1986

[5] S. Slameto, "Supervisi Pendidikan Oleh Pengawas Sekolah," Kelola: Jurnal Manajemen Pendidikan, vol. 3, no. 2, pp. 192-206, 2016

[6] J.C. de Almeida, "Teacher performance evaluation: The importance of performance standards," International Journal for Cross-Disciplinary Subjects in Education, vol. 8, no. 1, pp. 2973-2981, 2017.

[7] P. Smith and J. Sype, Corrective Action Corrective Action. p. 31.

[8] E. Bureau, Teacher Performance Management. Education and Manpower Bureau, 31, 2003. 